УДК 37.015.3:[37.091.12:005.963-057.86]:37.014

DOI: $10.37026 / 2520-6427-2019-99-3-92-95$
Людмила СМОЛЬСЬКА,

кандидатка психологічних наук, доцентка кафедри педагогіки, психології та корекиійної освіти Рівненського ОІППО

\title{
ПСИХОЛОГІЗАЦІЯ ОСВІТИ
} ЯК НЕОБХІДНА УМОВА ПІДВИЩЕННЯ ПРОФЕСІОНАЛІЗМУ ПЕДАГОГІВ НОВОЇ УКРАЇНСЬКОЇ ШКОЛИ

Стаття присвячена психологізації як освітній стратегії Нової української школи. У ній порівнюються поняття психологізму та психологізації; з'ясовуються кониептуальні засади НУШ, шо відповідають психологізаиіі; визначається ресурс та перспективи психологізації в післядипломній педагогічній освіті. Виокремлюються структурні частини цилісної стратегї психологізації, в якій суб'єкт реалізує певну ідеальну модель. Дається визначення означеного поняття з уточненнями смислових акиентів на конструктиві відповідно до иінностей, суб 'єктності, інтегральності та інтерактивності.

Ключові слова: психологізачія, освітня стратегія, партнерство, проивітання, інтегральне лідерство, інтерактивні форми.

Статья посвящена психологизащии как образовательной стратегии для Новой украинской школь. В ней сравниваются понятия психологизма и психологизации; выясняются концептуальные основы НУШ, соответствующие психологизации; определяется ресурс и перспективы психологизации в последипломном педагогическом образовании. Выделяются структурные части иелостной стратегии психологизаиии, в которой субъект реализует определённую идеальную модель. Даётся формулирование указанного проиесса с уточнением смысловых акцентов на конструктиве в соответствии с иенностями, субъектностью, интегральностью и интерактивностью.

Ключевые слова: психологизация, образовательная стратегия, партнёрство, прочветание, интегральное лидерство, интерактивные формыл.

The article is devoted to psychologisation as educational strategy in conditions for New Ukrainian school. It calls to move far out from traditional authoritarian system with its overloading and isolating pushes into neurotization. New school should be based on humanism, partnership, integrality.

The author compares notions of psychologism and psychologisation; searches for points of link between psychologisation and conceptual basics of New Ukrainian school; structurally defines potential of psychologisation in postgraduate pedagogical education with concrete examples.

Psychologisation is identified here as strategy for systematical realization by subject of some ideal model, which is constructed from affiliated social values and psychological notions. Subject can be considered as a person or a command. It is proposed to associate ideal model with psychological criteria of flourishing.

In the article are shown few important points in the Concept of New Ukrainian school to which educational psychologisation appeals. They are: pedagogy of partnership, which is based on mutual respect between all members of educational process; motivated teachers who have got necessary stimuli for making integral leadership; direction to unique personality in order to satisfy each student's needs; making bringing up process with values as integral educational stream; constructing of modern educational environment which stimulates creative resources in both-students and teachers. The author claims that educational psychologisation encourages professional educators to move from authoritarian communicational roles to horizontal partnership with considering both empathy and completing tasks as equally important tools for making flourishing. The link between the challenging uncompleted content of tasks and growing motivation for studying is obvious in interactive forms of study process. Psychologisation in postgraduate pedagogical education contains new research and methodical activity as well as using interactive forms of professional study.

Key words: psychologisation, educational strategy, partnership, flourishing, integral leadership, interactive forms.

Постановка проблеми. Психологізація як апелювання до «душевності», «олюднення» набуває поширення в багатьох життєвих галузях як відповідь на відчужуючий деструктивний поступ цивілізації. Відчужене навчання, як і відчужена вчительська праця, давно стало невротизуючою повсякденністю. Нівелююча особистості традиційна освіта $з$ іiі авторитарністю, перевантаженнями та догматизмом не здатна проектувати якісне життя. Як наслідок - маємо найвищі у Свропі показники з корупції, бідності, захворюваності, залежностей, психічних відхилень, демографічного регресу та смертності.

Нова українська школа має стати локомотивом для соціальної трансформації, де люди єднатимуться для процвітання. Тому так важливо втілювати закладені в неї ідеї гуманізму, партнерства, інтегральності тощо на основі цілісної стратегії. Однак психологічної готовності педагогів працювати по-новому, досліджень щодо зазначених НУШ генеральних напрямів на рівні стратегії психологізації, розробок тактичної конкретики бракує. 
Аналіз наукових досліджень і публікацій. Розгляд літератури щодо проблематики втілення психологічних знань у педагогічну практику свідчить, що цими питаннями займалася ціла плеяда вчених-класиків. У сучасній науці питанням психологічної готовності до інноваційної діяльності присвятили свої роботи М. Боришевський, Г. Головін, В. Загвязинський, Н. Клокар, Н. Мітіна, С. Павлютенков, Н. Попель, О. Соснюк та ін. Психологічна готовність до нового лідерства в сучасних умовах знайшла відображення в дослідженнях В. Татенка, О. Бондарчук, Л. Карамушки, А. Москальової.

Варто зауважити, що із 2017 року була розгорнута масштабна програма «Інтегральне лідерство в освіті», ініційована консорціумом організацій «Вільна хата», Міжнародним інститутом інтегрального розвитку «Empatia.pro» за підтримки Посольства Литви в Україні та Програми розвитку і співробітництва зі Шведським інститутом. У межах проекту було розроблено концептуальні основи Нової української школи та запущено систему поетапної комплексної підготовки педагогів як інтегральних лідерів по всій країні. Якщо у школі вчитель має бути сильним ядром живої клітини, спільної з дітьми цільності, то в структурі підвищення фахової кваліфікації таку ж роль, підсилену психологічними знаннями та досвідом, відіграє викладач. Із цим співзвучні ідеї С. Калашнікової, Л. Калініної, О. Бондарчук, Л. Карамушки, В. Олійника, М. Москальова, Л. Набоки, Т. Сорочан.

Мета статті полягає в 3'ясуванні змісту стратегії психологізації професіоналізму в післядипломній педагогічній освіті за умов розбудови Нової української школи.

Зважаючи на мету, основними завданнями статті є: порівняння суміжних, а не тотожних понять «психологізм» та «психологізація»; з'ясування психологізації Нової української школи відповідно до іiі концептуальних засад; визначення потенціалу психологізації в післядипломній педагогічній освіті.

Виклад основного матеріалу. Усі попередньо згадані дослідження засвідчують важливість психологізму в освітньому процесі, неабияку роль психологічних знань у кращому розумінні професійної реальності. При цьому наука тлумачить психологізм як певний аналіз - інтерпретацію подій та факторів із позиції наукових концепцій психології [2]. Психологізачія ж асоціюється передусім із цілеспрямованою діяльністю, в якій акцентується синтез. Так, В. С. Маслов у зв'язку 3 цим зазначає: «Психологізація навчання потребує від викладача значного збільшення уваги до своєї професійної кваліфікації, до глибокого опанування можливостей психологічного дослідження та практичного застосування його результатів» [5, с. 58].

Визначимо психологізацію як стратегію системного втілення в життя певної ідеальної моделі суб ' $\epsilon \kappa-$ $m a$, створеної на основі привласнених суспільних цінностей та пізнання психологічних закономірностей і факторів. Особливе змістове навантаження - на суб' єктності. Нова освіта проголошує кожного, в ній залученого, суб'єктом самонавчання, самомотивування, саморозвитку, самореалізації [6]. Психологізація - це і командна, й особистісна стратегія на процвітання відповідно до набутих психологічних знань та особисто прийнятих пріоритетів НУШ.

У Концепції Нової української школи визначено такі напрями, які можуть розглядатися як складові психологізації: «педагогіка партнерства, що грунтується на взаємоповазі між усіма учасниками освітнього процесу»; «вмотивований учитель, який має необхідні кваліфікації та стимули, щоб стати лідером змін»; «орієнтація на неповторність особистості й індивідуальний підхід до задоволення потреб кожного учня»; «виховання на цінностях як інтегральна складова освітнього процесу»; «створення сучасного освітнього середовища, що стимулюватиме вивільнення творчого потенціалу як учнів, так і педагогів» [6].

Освітня психологізація - це шлях осмисленого конструктиву в професійній діяльності, позитивній взаємодії освітніх суб'єктів між собою та світом. Цей шлях індивідуальний, однак грунтується на цінностях суспільства. Спрямованість на процвітання для сталого розвитку - це ідеал, місія освіти. Із цією метою вона має стати провайдером нової соціальної практики інтегрального лідерства та самолідерства. Сьогодні маємо відмовитися від деформуючих стереотипів споживацтва та нарцисизму й відновити свою вищу людську природу - стати чуйними і продуктивними творцями блага. В освіті маємо перейти до активного партнерського пізнання й практикування 3 високим рівнем самостійності й компетентної результативності. Так ми турбуватимемось про особистість кожного, про його гідність, самоповагу, саморозвиток й самореалізацію. У Законі України «Про вищу освіту» у статті 137 про це йдеться як про головне освітне завдання [3].

Нова українська школа визначає пріоритети високих стандартів у чітко зазначених компетенціях та якостях громадянської зрілості, які можна формувати, враховуючи психологічні механізми та чинники розвитку людини в іiї середовищі. Психологічний ресурс збагачення освітнього середовища, створення на основі психологічного пізнання найвпливовіших у ньому позитивних чинників - складова психологізації Нової української школи. Професійні команди в закладах післядипломної педагогічної освіти мають сприяти створенню такого середовища, в якому педагоги мотивуються до міжособистісної горизонталі - відмовляються від соціально-поведінкових рефлексів авторитарності на користь гуманних, креативних, інтерактивних методів.

Із 2016 року в Рівненському ОІППО в межах лабораторії психології професіоналізму під керівництвом О. I. Бондарчук досліджується ідея психологізації, що грунтується на якісному покращенні професійного ресурсу освітян як перспективи трансформації у широкому соціумі.

Психологізацію можна розглядати і як систему професійних дій фахівців, спрямованих на створення оптимальних освітніх умов для особистісного саморозкриття та росту, неперервної соціалізації, компетентнісної надійності та гнучкості.

За підтримки лабораторії було проведено низку заходів:

1) Запущено процес пошуку концептуальних основ освітньої психологізації на кафедрі педагогіки, психології та корекційної освіти РОІППО, що відображається у творчій професійній діяльності викладачів. Так, до цих основ відносимо вивчення й творчі інтерпретації: існуючих та перспективних підходів позитивної психології; філософсько-екзистенційних ідей щодо процвітання, інтегральності; сучасного інтегрального лідерства. Особлива увага в дослідженнях приділяється освітній мотивації. 
2) Створено експериментально-пілотні майданчики у Здолбунівському та Костопільському районах Рівненської області, де шкільним психологам запропоновано: а) діагностичний інструментарій для виявлення проблемних зон готовності педагогів працювати на засадах гуманістичних відносин та пріоритетів; б) розробку й упровадження методів заміни психологічної парадигми «авторитарної вертикалі» на «особистісну горизонталь» за умов творчого партнерства між собою, із працівниками РОІППО, членами лабораторії.

3) Модифіковано відповідно до психологічних пріоритетів, затверджених Концепцією НУШ, наказами й рекомендаційними листами $\mathrm{MOH}$ України, один із навчальних модулів до освітніх програм на курсах підвищення кваліфікації, що має назву «Педагогічна психологія та корекційна освіта».

4) Науково-педагогічним складом кафедри педагогіки, психології та корекційної освіти РОІППО розроблено теми для реалізації стратегії підвищення психологічної готовності освітян працювати в Новій українській школі, які стосуються сприяння підвищення батьківської компетентності в питаннях розвитку особистості засобами сімейного впливу, оскільки найближчі члени родини є партнерами зі створення умов повного розкриття ресурсів дитини. Прикладом однієї із таких тем є «Актуальні проблеми розвитку психолого-педагогічної культури батьків в умовах партнерства НУШ».

5) Навчальні теми модуля «Педагогічна психологія та інклюзивна освіта» пропонуються в інтерактивних формах навчання, які значною мірою відповідають психологічним потребам курсантів у спілкуванні, власній значимості, самовираженні, творчості, подоланні перешкод, різноманітті. Умовою інтерактивності завдань $€$ їхня неповнота, незавершеність та неоднозначність. У завданнях має бути простір для творчих інтерпретацій, продовжень, модифікацій. Усе це - відмова від догматичних «знань», що раніше подавалися в прямо або потенційно готовому вигляді на зразок «здогадайся відповідь і догоди викладачеві».

6) Викладачами кафедри педагогіки, психології та корекційної освіти РОІППО Л. М. Смольською та Л. Р. Тищенко розроблено і видано матеріали, що підвищують психологічну компетентність педагогів, конкретизують способи ії використання у професійній діяльності [9; 8].

У межах реалізації означених напрямів запропоновано авторський «інформаційно-дискутивний практикум» як інноваційну інтерактивну форму спільної освітньої діяльності викладача і курсантів. У ній виокремлюємо певні особливості. По-перше, інформація подається викладачем та «переробляється» курсантами частинами; у кожну частину включено: слухання, коротке нотування символами та малюнками, письмове бліц-виконання творчого завдання. По-друге, інформація в кожному сегменті виступає не догмою, а радше умовою своєрідного бліц-завдання, яке здобувач освіти має індивідуально вирішити й зафіксувати. По-третє, невеликі групи, що утворюються в другій половині заняття мають можливість як партнери подискутувати між собою та прийняти колективне рішення за відведений час. По-четверте, групи мають представити на загал своє бачення проблематики у вигляді презентованого проект-макета, наприклад: «Моя авторська школа», «Турботлива школа», «Школа процвітання».

Висновки. Психологізм як пояснення явищ та факторів із позиції закономірностей і теорій психології - необхідна, але недостатня умова психологізації, яка $є$ комплексною освітньою стратегією.
Крім використаних психологічних знань, суб'єкт концентрується на соціально ціннісному, бажаному, моделює його досягання в збагаченому середовищі та партнерстві, вчиться самолідерству та інтегральності.

Психологізація в післядипломній педагогічній освіті на етапі розбудови Нової української школи - шлях індивідуальної та колективної творчості освітян 3 дотриманням запитів суспільства на гуманізацію та професіоналізм в умовах та перспективах постійних змін.

Перспектива подальших науково-методичних досліджень та прикладних розробок щодо психологізації передбачає розгляд цілісної психологічної проблематики в її компонентах: неперервної соціалізації, збагаченого освітнього середовища, самолідерства, інтегральності, горизонтального спілкування, внутрішньої мотивації освітньої діяльності.

\section{СПИСОК ВИКОРИСТАНОЇ ЛІТЕРАТУРИ}

1. Бондарчук О. I. Психологічна безпека освітнього середовища закладів загальної середньої освіти та iї вплив на мотивацію інноваційної діяльності вчителів / О. І. Бондарчук // Вісник післядипломної освіти. - 2017. - Вип. 4-5. - С. 17-27. - (Серія «Соціальні та поведінкові науки»).

2. [Електронний ресурc]. URL: https://www. merriam-webster.com/dictionary/psychologism (дата звернення: 12.06.2019).

3. Закон України «Про вищу освіту» від 01.07.2014 №1556-VII [Електронний ресурс]. URL: https://zakon. rada.gov.ua/laws/show/1556-18/stru (дата звернення: 10.06.2019).

4. Карамушка Л. М. Формування психологічної готовності персоналу вищої школи до діяльності в умовах соціально-економічних змін : монографія / Л. М. Карамушка, О. С. Толков. - Кам'янець-Подільський : Медобори-2006, 2013. - 260 с.

5. Маслов В. С. Психологізація навчання / В. С. Маслов // Вісник Національного університету оборони України. - 2012. - Вип. 2 (27). - С. 54-58.

6. Нова українська школа [Електронний ресурс]. URL: http://mon/gov/ua/2016/12/05/konczepcziya.pdf (дата звернення: 16.06.2019).

7. Олійник В.В.Відкрита післядипломна педагогічна освіта: стан та перспективи розвитку / В. В. Олійник // Післядипломна освіта в Україні. 2017. - № 1. - С. 3-11.

8. Світ душі. Виховання на цінностях : навчально-методичний посібник // авт.-укл. Л. Р. Тищенко. Рівне : РОІППО, 2018. - 240 с.

9. Смольська Л. М. Психолого-педагогічний практикум інтерактивного навчання в післядипломній педагогічній освіті / Л. М. Смольська. - Рівне : РОІППО, 2018. - 97 с.

10. Сорочан Т. М. Розвиток професіоналізму керівників загальноосвітніх навчальних закладів в умовах реалізації концепції «Нова українська школа» / Т. М. Сорочан // Керівник нової української школи: світоглядно-професійні орієнтири : збірник наукових праць / В. П. Андрущенко, В. П. Бех та ін. - Київ : Вид-во НПУ ім. Драгоманова, 2017. - С. 153-158.

11. Bondarchuk O. Subjective well-being of university teachers as a psychological factor of quality of higher education / O. Bondarchuk // Management of higher education quality: problems and prospects : collection of scientific papers ; ed. Victor Oliynyk. - London : LASHE, 2017. - P. 86-89.

Дата надходження до редакиіï: 21.06.2019 p. 